\title{
BIOCHEMICAL SERUM PROFILE OF QUARTER MILE EQUINES IN TEAM PENNING TRAINING
}

\author{
CARACTERIZAÇÃO DO PERFIL BIOQUÍMICO SÉRICO EM EQUINOS QUARTO \\ DE MILHA SUBMETIDOS AO TREINAMENTO PARA TEAM PENNING
}

\section{Roberta de Lima SANTOS ${ }^{1 *}$; Renata Dias RODRIGUES ${ }^{1}$; Lara Reis GOMES ${ }^{1}$; Amanda BIZARE ${ }^{2}$; Wilson Junior OLIVEIRA ${ }^{1}$; Rafael Rocha de SOUZA ${ }^{\mathbf{1}}$; Felipe Cesar GONÇALVES ${ }^{1}$; Antonio Vicente MUNDIM ${ }^{1}$}

1. Universidade Federal de Uberlândia, Faculdade de Medicina Veterinária, Uberlândia, MG, Brazil; *robertalimasantos@hotmail.com; 2. Universidade Estadual Paulista - UNESP, Faculdade de Ciências Agrárias e Veterinárias, Jaboticabal, Jaboticabal, SP, Brazil.

\begin{abstract}
The objective of this work was to evaluate the proteins, minerals, metabolites, and serum enzymes profile in Quarter Mile equines subjected to training for Team Penning competitions by comparing the results before and after training. The animals were from the Agricultural Exhibition Park of Uberlândia (CAMARU), in Uberlândia in the State of Minas Gerais, Brazil. These animals perform constant periodic training with an average duration of two and a half hours per training. Blood samples from twenty male and female equines were collected at the beginning and end of a 45-day interval and then analyzed. A 5 $\mathrm{mL}$ blood sample from each animal was collected before and after training by a jugular external venipuncture, and the samples were placed in a tube-without anticoagulant and containing separator gel - to obtain the serum. The components analyzed were: total proteins, albumin, globulins, albumin to globulin ratio (A:G), total and ionized calcium, phosphorus, calcium to phosphorus ratio $(\mathrm{Ca}: \mathrm{P})$, cholesterol, triglycerides, creatinine, urea, alkaline phosphatase, $\gamma$-glutamyl transferase, lactate dehydrogenase (LDH), aspartate amino transferase (AST), alanine aminotransferase (ALT) and creatine kinase (CK). Statistical differences were observed with higher values after exercise for total calcium, ionized calcium, Ca: P ratio, creatinine and ALT and decreased concentrations were found for globulins, phosphorus, cholesterol and triglycerides. Despite the changes observed in the serum concentrations of some elements after exercises, it was concluded that the animals were in adequate physical condition to perform the proposed physical exercises.
\end{abstract}

KEYWORDS: Horse. Metabolites. Proteins. Serum enzymes. Training.

\section{INTRODUCTION}

Team Penning is an intense sport practiced in an arena by three riders. They try to separate three calves from a herd based on their randomly drawn number. The goal is to separate these calves from the herd in a corral installed on the opposite side of the arena in the shortest possible time. According to Aiello (2001), this type of exercise requires the horses to achieve maximum speed in short duration; then, the Adenosine Triphosphate (ATP) intramuscular deposits deplete by $50 \%$, leading to lactate accumulation and presence of ammonia in the muscles, which intensifies muscle fatigue.

In this context, studies on the clinical biochemistry of equine athletes are essential to identify the physiological conditions of these animals and the burden of their proposed exercises. The biochemical analysis of the animal's blood is used to evaluate the functioning of several systems, especially the hepatic and renal systems (THRALL et al., 2007). Calcium, phosphorus, magnesium, glucose, cholesterol, triglycerides, total protein, albumin, transaminases (TGP and TGO), alkaline phosphatase, creatinine, urea, and bilirubin are the most important elements within the clinical routine (GONZÁLEZ; SILVA, 2006).

The biochemical serum profile of each equine athlete before and after exercise can be established through laboratory diagnosis, which promotes a reduced occurrence of possible injuries to the animal's body systems due to the practice of sports. In this context, the objective of this work was to evaluate the proteins, minerals, metabolites, and serum enzymes profiles in Quarter Mile equines subjected to training for Team Penning competitions by comparing the results before and after training.

\section{MATERIAL AND METHODS}

This study was previously approved by the Ethics Committee for Animal Use of the Federal University of Uberlândia (CEUA-UFU), according to registration protocol $084 / 13$. 
This work evaluated twenty male and female Quarter Mile equines with an average age of four years from the Agricultural Exhibition Park of Uberlândia (CAMARU), Uberlândia in the state of Minas Gerais, Brazil. These animals were trained for Team Penning for two and a half hours, twice a week.

The feeding of these animals consisted of 4 $\mathrm{kg}$ of balanced feed with a concentration of $13 \%$ crude protein, $12 \%$ moisture, $2 \%$ ethereal extract, $14 \%$ fibrous matter, $10 \%$ mineral matter, $1.5 \%$ calcium, $0.5 \%$ phosphorus, and $69 \%$ total neutral detergent fiber. This was divided and fed to the equines two times a day: at 8:00 a.m. and 2:00 p.m. In addition, $4 \mathrm{~kg}$ of hay was offered at 5:30 p.m. They (the animals or the food) were placed on the pasture two days a week for two and a half hours, between 8:30 a.m. and 11:30 a.m., and between 3:30 p.m. and 5:00 p.m.

The animals were housed in stalls and bathed twice a week. The stalls were sanitized every day, and the automatic water drinkers twice a week. All animals were evaluated for Equine Infectious Anemia every two months and their horseshoes received maintenance every thirty days. All the animals were up to date with the recommended immunization schedule.

Jugular venipuncture was used to obtain 5 $\mathrm{mL}$ blood samples from each animal at the beginning and end of a 45-day interval using a blood collection adapter (BD Vacutainer ${ }^{\mathbb{B}}$ ), a disposable needle for the adapter, and a tube without anticoagulant and containing separator gel $\left(\mathrm{BD}^{\circledR}\right)$. The first blood collection was carried out fifteen minutes before and the second sixty minutes after the training for Team Penning. The collection was always at night between 6:30 p.m. and 10:00 p.m., due to the training sessions being held from 7:00 p.m. to 9:20 p.m. The blood samples were kept in isothermal boxes until the morning of the following day when they were sent to the Veterinary Laboratory of the Federal University of Uberlândia (LACVET-UFU).

In the laboratory, the samples were centrifuged at $720 \times \mathrm{g}$ for 5 minutes. The obtained serum was separated in aliquots into microtubes (Eppendorf) to evaluate the serum concentrations of total protein (Biuret method), albumin (green method of bromocresol), calcium (cresolphthalein complexone method), phosphorus (ultraviolet kinetic method), total cholesterol (Trinder enzyme method), triglycerides (Trinder enzyme method), creatinine (alkaline picrate method), urea (kinetic enzymatic method), alkaline phosphatase (optimized kinetic method), $r$-glutamyl transferase (modified
Szasz method), dehydrogenase lactatato (LDH) (pyruvate lactate method), aspartate amino transferase (AST) (ultraviolet kinetic method), alanine aminotransferase (ALT) (kinetic method UV IFCC), and creatine kinase (CK) (IFCC method) in a ChemWell multichannel automatic analyzer (Awareness Technology, Inc. ${ }^{\circledR}$ ) by using commercial kits from Labtest Diagnostica ${ }^{\circledR}$. This automatic analyzer was previously calibrated with calibrator $\mathrm{H}$ and measured with universal control serum qualitrol $\mathrm{H}$. Both were produced by Labtest Diagnostica $^{\circledR}$. The value of the globulins was determined by the difference between albumin and total proteins. The albumin to globulin ratio (A:G) and the calcium to phosphorus ratio $(\mathrm{Ca}: \mathrm{P})$ was also determined. The ionized calcium was determined according to the recommendations of the kit manufacturer.

The normality of difference between the data collected before and after the training for Team Penning was tested by using the KolmogorovSmirnov test (KS) at 5\% significance. The $t$ test was applied to paired samples when the normality of the data was confirmed, and the Wilcoxon test was performed when it was not.

\section{RESULTS}

Significant differences $(p<0.05) \quad$ were observed in the globulins, calcium, ionized $\mathrm{Ca}^{2}$, phosphorus, Ca:P, cholesterol, triglycerides, creatinine, and ALT when comparing values of the biochemical serum constituents from before and after training (Table 1). 
Table 1. Mean values, standard deviation (SD), and statistical analysis of the biochemical serum components of Quarter Mile equines before and after training for Team Penning sport.

\begin{tabular}{|c|c|c|c|c|}
\hline $\begin{array}{l}\text { Biochemical } \\
\text { components }\end{array}$ & $\begin{array}{c}\text { Reference } \\
\text { Values }\end{array}$ & $\begin{array}{c}\text { Before } \\
\text { Mean (SD) }\end{array}$ & $\begin{array}{c}\text { After } \\
\text { Mean (SD) }\end{array}$ & $p$-value \\
\hline Total protein $\left(\mathrm{g} \mathrm{dL}^{-1}\right)$ & $5.2-7.9$ & $8.49(1.90)$ & $8.30(1.68)$ & 0.1081 \\
\hline Albumin $\left(\mathrm{g} \mathrm{dL}^{-1}\right)$ & $2.6-3.9$ & $2.90(0.51)$ & $2.94(0.56)$ & 0.4266 \\
\hline Globulins ( $\left.\mathrm{g} \mathrm{dL}^{-1}\right)$ & $2.6-4.0$ & $5.59(1.44)$ & $5.36(1.26)$ & 0.0309 \\
\hline A to $G$ ratio & $0.5-1.7$ & $0.53(0.07)$ & $0.56(0.10)$ & 0.0554 \\
\hline Calcium (mg dL $\left.{ }^{-1}\right)$ & $11.2-13.6$ & $11.48(1.75)$ & $11.92(1.98)$ & 0.0038 \\
\hline $\mathrm{Ca}++$ ionized & 6-7.2 & $6.42(0.56)$ & $6.63(0.72)$ & 0.0232 \\
\hline Phosphorus (mg dL ${ }^{-1}$ ) & $3.1-5.6$ & $3.14(0.53)$ & $2.34(0.68)$ & 0.0000 \\
\hline $\mathrm{Ca}$ to $\mathrm{P}$ ratio & $1: 1-3: 1$ & $3.70(0.52)$ & $5.54(1.90)$ & 0.0000 \\
\hline Cholesterol $\left(\mathrm{mg} \mathrm{dL}^{-1}\right)$ & $75-150$ & $77.30(16.17)$ & $72.80(16.63)$ & 0.0082 \\
\hline Triglycerides $\left(\mathrm{mg} \mathrm{dL}^{-1}\right)$ & $4-44$ & $27.60(11.48)$ & $23.35(9.85)$ & 0.0306 \\
\hline Creatinine $\left(\mathrm{mg} \mathrm{dL}^{-1}\right)$ & $1.2-1.9$ & $1.66(0.32)$ & $2.08(0.58)$ & 0.0000 \\
\hline Urea $\left(\mathrm{mg} \mathrm{dL}^{-1}\right)$ & $21-51$ & $46.70(21.55)$ & $42.93(12.72)$ & 0.2238 \\
\hline Alkaline phosphatase $\left(\mathrm{U} \mathrm{L}^{-1}\right)$ & $0-395$ & $141.90(60.98)$ & $129.38(64.76)$ & 0.1744 \\
\hline $\mathrm{GGT}^{1}\left(\mathrm{UL}^{-1}\right)$ & $0-62$ & $15.14(8.29)$ & $14.04(7.94)$ & 0.3848 \\
\hline $\mathrm{LDH}^{2}\left(\mathrm{UL}^{-1}\right)$ & $162-412$ & $884.13(237.60)$ & $728.75(319.52)$ & 0.0573 \\
\hline $\operatorname{AST}^{3}\left(\mathrm{U} \mathrm{L}^{-1}\right)$ & $0-6$ & $183.66(57.65)$ & $181.20(67.88)$ & 0.6089 \\
\hline $\operatorname{ALT}^{4}\left(\mathrm{U} \mathrm{L}^{-1}\right)$ & $0-23$ & $20.59(27.77)$ & $23.61(26.66)$ & 0.0191 \\
\hline $\mathrm{CK}^{5}\left(\mathrm{U} \mathrm{L}^{-1}\right)$ & $0-140$ & $394.75(609.05)$ & $524.21(1197.75)$ & 0.0727 \\
\hline
\end{tabular}

The $\mathrm{t}$ test was used for normal distribution and the Wilcoxon test was used for abnormal distribution. The $p$-value for the $\mathrm{t}$ and Wilcoxon tests is 0.05 . Reference values from the parameters were established by Kaneko et al. (2008) for the species.

\section{DISCUSSION}

The contents of the biochemical serum components from the Quarter Mile equines evaluated before and after training were compared with the parameters established by Kaneko et al. (2008). The results of this comparison showed an increase in the mean contents of total proteins, globulins, AST, LDH, CK, ALT, and creatinine before and after training, whereas the mean contents of phosphorus and cholesterol were lower after training.

The differences between the mean contents found in this work and those of reference established by Kaneko et al. (2008) can be attributed to the individual physiological variations, management, age, environmental factors, and different methodologies used by the researchers.

The mean globulin content significantly reduced after training. This result is attributed to enzymatic degradation of globulins during exercise, as stated by Piccione et al (2009). There was a slight decrease in total protein concentration, although there was no significant statistical difference. This result does not confirm those of Miranda et al. (2009) and Noleto et al. (2016), who evaluated the hemato-biochemical elements of equines subjected to physical exercise; they found an increase in the total proteins because of the increase in globulins with similar albumin content in three evaluations. This denotes that acute phase proteins occur due to muscle injury processes (FAZIO et al., 2010).

In addition, total and ionized calcium concentrations increased after training. This result can be attributed to the slight reduction in plasma volume (hemoconcentration) after exercise and fluid loss by sweating. In a recent study it was found that the loss of this electrolyte by sweat was very small, which did not significantly interfere with calcium concentrations after three-barrel training (GOMES, et al. 2019). Miranda et al. (2009) reported similar results in a study on equines subjected to Team Penning training with an increase in $\mathrm{Ca}^{++}$serum levels.

The phosphorus contents significantly reduced after training. The skeletal striated muscle produces Adenosine Triphosphate (ATP) as an immediate source of chemical energy (SECANI; LÉGA, 2009), and phosphorus is required for the ATP dephosphorylation, which justifies the reduction of serum levels of this mineral after training. The $\mathrm{Ca}$ to $\mathrm{P}$ ratio showed a significant increase after training as a consequence of the decreased phosphorus. Zobba et al. (2011) and Noleto et al. (2016) also found a reduction in the phosphorus contents in equines subjected to physical exercise tests and they attributed this reduction to the adequate physical conditioning of 
Biochemical serum profile...

the animals since a greater intracellular movement is required for muscle function.

The cholesterol and triglyceride contents were significantly decreased after training. This result is due to the organism using these components to quickly obtain energy through the anaerobic pathway. According to Melo et al. (2013), the lipids present in the blood are important for animals that are subject to high performance exercises because this component is used significantly as an energy source for muscle work. Sloet Van Aoldruitenborgh-Ooserban et al. (2002) also found a significant reduction in total serum cholesterol concentration in equines after exercise.

The equines' creatinine contents had a significant increase after training due to the creatine and muscular phosphocreatine catabolism to obtain energy, corroborating earlier studies that have demonstrated modifications in the metabolism of proteins by muscles (MÉLO, et al., 2017). Creatinine increased significantly after the marcha gait simulation test (MÉLO, et al., 2017). This result can also be attributed to dehydration (RIBEIRO et al., 2004). Miranda et al. (2009) found an increase in the levels of the serum creatinine after exercise, whereas Noleto et al. (2016) reported similar creatinine contents before and after exercise.

The ALT contents had a significant increase after training due to fatigue or muscle injury caused by intense training, although the other muscle
SANTOS, R. L. et al.

function biomarkers (LDH, AST, CK) before and after exercise did not show statistically significant variation. Therefore ALT is not useful for predicting liver diseases in horses (REEDER et al., 2009).

This result is corroborated by Yang et al. (2009) and Noleto et al. (2016), who found an increase of the ALT enzyme in the equine breed Mangalarga Marchador after being subjected to physical exercise.

The contents of LDH, AST, and CK enzymes in the animals evaluated before and after training were different than those of Miranda et al. (2009), who found statistically significant increase for these enzymes in the animals after practicing Team Penning. However, they were similar to those found by Da Cás et al. (2000), who evaluated Criollo equines subjected to physical exercise. Gama et al. (2012) found no differences in AST and CK serum concentrations in Mangalarga Marchador equines before and after physical exercise.

Therefore, despite the biochemical serum changes found in the Quarter Mile equines subjected to training for Team Penning, the results presented animals in adequate physical condition to perform the proposed physical exercise. However, serum biochemical laboratory evaluations are necessary to evaluate and determine the physiological profiles appropriate for those recommended for animal health.

RESUMO: O presente estudo objetivou comparar o perfil de proteínas, metabólitos, minerais e enzimas séricas em equinos Quarto de Milha submetidos a treinamento para provas de Team Penning no Parque de Exposições Agropecuárias de Uberlândia (CAMARU), Uberlândia-MG. Os animais realizavam treinos periódicos e constantes com duração de duas horas e meia em média. Foram analisadas 40 (quarenta) amostras de sangue de 20 (vinte) equinos, machos e fêmeas, coletadas em dois momentos com intervalo de 45 dias. Por meio de venopunção jugular externa, coletou-se $05(\mathrm{~mL})$ de sangue em tubo sem anticoagulante e contendo gel separador para obtenção de soro, antes e após o treinamento de cada momento. Os constituintes analisados foram proteínas totais, albumina, globulinas, relação albumina globulina (A:G), cálcio total e ionizado, fósforo, relação cálcio fósforo $(\mathrm{Ca}: \mathrm{P})$, colesterol, triglicérides, creatinina, ureia, fosfatase alcalina, $\gamma$ glutamiltransferase (GGT), lactato desidrogenase (LDH), aspartato aminotransferase (AST), alanina aminotransferase (ALT) e creatina quinase (CK). Sendo observado diferenças estatísticas com valores mais elevados após o exercicio para cálcio total, cálcio ionizado, relação Ca:P, creatinina e ALT e concentrações diminuidas para globulinas, fósforo, colesterol e triglicérides. Apesar das alterações observadas nas concentrações séricas de alguns elementos após a prática esportiva, conclui-se que os animais se encontravam em condicionamento físico adequado para realizarem os exercícios físicos propostos.

PALAVRAS-CHAVE: Cavalo. Enzimas séricas. Metabólitos. Proteínas. Treinos.

\section{REFERENCES}

AIELLO, S. E. Manual Merck de Veterinária. 8. ed. São Paulo: Editora Roca, 2001. 1861 p. 
DA CÁS, E. L.; ROSAURO, A. C.; SILVA, C. A. M.; BRASS, K. E. CK, AST e LDH seric concentration in crioulo breed horses. Ciência Rural, v. 30, n. 4, p. 625-629, 2000. http://dx.doi.org/10.1590/S010384782000000400011

FAZIO, F.; ASSENZA, A.; TOSTO, F.; CASELLA, S.; PICCIONE, G.; CAOLA.; G. Modifications of some acute phase proteins and the White blood cell count in thoroughbreds during training. Veterinary Record, $v$. 167, n. 10, p. 370-372, 2010. http://dx.doi.org/10.1136/vr.c3761

GAMA, J. A. N.; SOUZA, M. S.; PEREIRA, N. E.; SOUZA, V. R. C.; COELHO, C. S. Concentrações séricas de aspartato aminotransferase e creatinoquinase e concentrações plasmáticas de lactato em equinos da raça Mangalarga Marchador após exercício físico. Brazilian Journal of Veterinary Research and Animal Science, v. 49, n. 6, p. 480-486, 2012. https://doi.org/10.11606/issn.1678-4456.v49i6p480-486

GOMES, C. L. N.; RIBEIRO FILHO, J. D.; SILVA, L. P.; ARANHA, R. M. C.; MORAES JÚNIOR, F. J.; CARDOSO, J. K. M.; MONTEIRO, L. C. Parâmetros fisiológicos e bioquímicos de equinos em treinamento de três tambores: pós-condicionamento, pós-percurso e pós-descanso. Arquivo Brasileiro de Medicina Veterinária e Zootecnia, v. 71, n. 2, p. 631-639, 2019. http://dx.doi.org/10.1590/1678-4162-10270

GONZÁLEZ, F. H. D.; SILVA, S. C. Introdução a bioquímica clínica veterinária. 2. ed. Porto Alegre: UFRGS, 2006. 358 p.

KANEKO, J. J.; HARVEY, J.W.; BRUSS, M. L. Clinical Biochemistry of Domestic Animals. $6^{\text {th }}$. ed. San Diego: Academic Press, 2008. 916 p.

MELO, S. K. M.; LIRA, L. B.; ALMEIDA, T. L. A. C.; REGO, E. W.; MANSO, H. E. C. C. C.; FILHO, H. C. M. Índices hematimétricos e bioquímica sanguínea no cavalo de cavalgada em condições tropicais. Ciência Animal Brasileira, v. 14, n. 2, p. 208-215, 2013. https://doi.org/10.5216/cab.v14i2.16484

MÉLO, S. K. M.; FERREIRA, L. M. C.; HUNKA, M. M.; BARBOSA, B. L.; ABREU, J. M. G.; MANSO, H. E. C. C. C.; MANSO FILHO, M. C. Marcha Gait Simulation Test Decrease Antioxidative Biomarkers in FourBeat Gaited Horses. Journal of Equine Veterinary Science. v. 55, n. 1, p. 12-17, 2017.

https://doi.org/10.1016/j.jevs.2017.02.018

MIRANDA, R. L.; MUNDIM, A. V.; SAQUY, A. C. S.; COSTA, A. S.; GUIMARÃES, E. C.; GONÇALVES, F. C.; SILVA, F. O. C. Biochemical serum profile of equines subjected to team penning. Comparative Clinical Pathology, v. 18, n. 3, p. 313-319, 2009. https://doi.org/10.1007/s00580-008-0803-6

NOLETO, P. G.; CUBAS, J. P. C.; BARBOSA, F. C.; GUIMARÃES, E. C.; MUNDIM, A. V. Biochemical profile of polo horses in training phase and those players of official competition. Comparative Clinical Pathology, v. 25, n. 4. p. 911-915, 2016. https://doi.org/10.1007/s00580-016-2281-6

PICCIONE, G.; CASELLA, S.; GIANNETTO, C.; MONTEVERDE, V.; FERRANTELLI, V. Exerciseinduced Modifications on Haematochemical and Electrophoretic Parameters During 1600 and 2000 Meters Trot Races in Standardbred Horses. Journal of Applied Animal Research, v. 35, n. 2, p. 131-135, 2009. https://doi.org/10.1080/09712119.2009.9707002

REEDER, D.; MILLER, S.; WILFONG, D. A.; LEITCH, M.; ZIMMEL, D. AAEVT's Equine Manual for Veterinary Technicians. 1st ed., United States: Iowa State University Press. 2009. 418 p.

RIBEIRO, C. R.; MARTINS, E. A. N.; RIBAS, J. A. S.; GERMINARO, A. Avaliação de constituintes séricos em equinos e muares submetidos à prova de resistência de $76 \mathrm{~km}$, no Pantanal do Mato Grosso, Brasil. Ciência Rural, v. 34, n. 4, p. 1081-1086, 2004. http://dx.doi.org/10.1590/S0103-84782004000400018

SECANI, A.; LÉGA, E. Fisiologia do exercício em equinos. Nucleus Animalium, v. 1, n. 2, p. 53-66, 2009. 
SLOET VAN OLDRRUITNBORGH-OOSTERBAN, M. M.; ANNEE, M. P.; VERDEGAAL, E. J.; LEMMENS, A. G.; BEYNEN, A. C. Exercise and metabolism associated blood values variables in Standardbred fed either a low or a high fat diet. Equine Veterinary Journal, v. 34, n. 34, p. 29-32, 2002. https://doi.org/10.1111/j.2042-3306.2002.tb05387.x

THRALL, M. A.; WEISER, G.; ALLISON, R. W.; CAMPBELL, T.W. Hematologia e Bioquímica Clínica Veterinária. 2. ed. São Paulo: Editora Roca, 2015. 688 p.

YANG, R.; PARK, S.; REAGAN, W. J.; GOLDSTEIN, R.; ZHONG, S.; LAWTON, M.; RAJAMOHAN, F.; QIAN, K.; LIU, L.; GONG, D. Alanine aminotransferase isoenzymes: Molecular cloning and quantitative analysis of tissue expression in rats and serum elevation in liver toxicity. Hepatology, v. 49, n. 2, p. 598-607, 2009. https://doi.org/10.1002/hep.22657

ZOBA, R.; ARDU, M.; NICCOLINIS, S.; CABEDDU, F.; DIMAURO, C.; BONELLI, P.; DENOLA, C.; VISCO, S.; PARPAGLIA, M. L. P. Physical, hematological, and biochemical responses to acute intense exercise in Polo horses. Journal of Equine Veterinary Science, v. 31, n. 9, p. 524-548, 2011. https://doi.org/10.1016/j.jevs.2011.03.010 